\title{
From a click to a gesture: a contribution to defining the concept of children's e-picturebooks
}

Ana Lúcia Pinto aluciapinto@gmail.com

Nelson Zagalo nzagalo@ics.uminho.pt

Eduarda Coquet coquet.eduarda@gmail.com

Universidade do Minho, Portugal

Reference

Pinto, Ana Lúcia; Zagalo, Nelson; Coquet, Eduarda; (2012) "From a click to a gesture: a contribution to defining the concept of children's e-picturebooks", p. 223-228. In: Barbosa, Helena; Quental, Joana [Eds]. Proceedings of the 2nd International Conference of Art, Illustration and Visual Culture in Infant and Primary Education. São Paulo: Blucher, 2015. ISSN 2318-695X, ISBN: 978-989-98185-0-7 DOI 10.5151/edupro-aivcipe-43

\section{Abstract}

This communication aims contribute to define the concept of children's e-picturebooks. There should be a reflection on this subject and on the place that e-picturebook occupies or may occupy, in the children's reading's field. Will be the focus of attention: a) generic characteristics of picturebooks; b) the specificities of e-picturebooks; c) the value that applied media, with its intrinsic qualities, assumes in e- picturebooks, together with the identification of some possibilities for the future's development of research on these artefacts, taking into account the increasing value of digital media, as mediators of multimodal nar- ratives, aimed at children.

\section{The children's picturebooks}

In mid-eighteenth century, two editors/booksellers from London - Thomas Boreman and John Newberry (Escarpit,1996) - published the first illustrated children's books, to "instruct and enter- tain". Those books, in which narrative is an image and text combination, are the ancestors of con- temporary picturebooks.

Throughout years the picturebooks suffered changes in design, in their material characteristics and in relationships between images and texts.

The early definitions of picturebooks were based on identification of its narrative and physical components. In the late twentieth century and first decade of this century, the emphasis shifted to the semantic relationships, decoding and interpretation of picturebook visual and verbal texts. Bar- bara Kiefer (2008) summarizes the approaches to the concept throughout the twentieth century as "artefact of culture that contained visual images and often words"; she even points us the printed paper, the hardcover bookbinding, the 32 pages, as materials characteristics. In conclusion she said that, during this period "the picturebook was created for the enjoyment of an audience of young children with the object of engaging them in pleasurable experiences."

If we consider only this approach to define picturebooks, we can hardly establish their specificity, since all books for children, use images and text or only images, to communicate.

Nikolajeva (2002) points out that the specificity of picturebooks "derives from the combination of two levels of communication, the verbal and the visual" asserting that "the picturebooks are a synthetic medium (...) the overall meaning is assembled by the receiver in the interaction between the different communicative means". Likewise, Wolfenbarger and Sipe (2007) state that "a new en- tity is revealed that is more than the sum of its parts".

In 2012 Sipe "revisits" some relationships between image and texto in the picturebooks and su- pports that the essential premise for all addressed perspectives is "a picturebook can only 
be fully understood when readers/viewers understand the intricate and dynamic relationships between the sign system of the visual images and the sign system of the words" (2012), assigning to reader/child and/or the mediators a key role in decoding. Understanding the codes allows the receiver to decode the plot, uncover meanings, identify signs and symbols presented and unveil the creation contexts of narratives from picturebooks, in accordance with Nikolajeva (2010).

Anstey (2008) points out intentional mechanisms used by authors and/or illustrators that are related with classification of picturebooks as postmodernist objects: non-traditional forms of dealing with the narrative; unusual use of narrator's voice; style's mixture; unusual formats; intertextuality; enhancement of multiple readings and meanings, for different audiences. The rise and evolution of digital media has brought us, nowadays, new ways to communicate: communication is increasingly built up by the aggregation of various media.

Terje Hillesund (2010) emphasizes that contemporary reading is often done in "interactive digi-

tal environments (...) that combines images, videos and music", i.e., contemporary reading is not only done in printed media, the digital texts are mainly multimodal and their reading requires interaction and navigation (Mangen,2008). The new books had emerged with various media and differ- ent characteristics, changing the reading experience.

Kress (2000) holds that "an adequate theory for contemporary multimodal textual forms, needs to be formulated so as to permit the description both of the specific characteristics of a particular mode and of its more general semiotic properties(...)".

\section{Digital interactive books for children ebook definition}

Chrystal (2009) define e-book as "an electronic or digital representation of a given text, whether scanned, typed, or programmed, having virtual "pages", that are read using e-book reading software, either on a personal computer, a PDA, a smart phone or on a dedicated e-book reading device".

In 1971, Michael Hart, author of the project Gutenberg, created the first e-book (Chrystal, 2009). For a long time this term was used for digital text with hypertextual interaction restrictions. The birth of specific devices for reading e-books and thereafter tablets (e.g. the Kindle and iPad) pro- pelled the format's evolution, the number of available titles and available genres.

Along with e-book, another reading digital formats combine in its terminology the "e" letter, for electronic (followed or not by an hyphen), with artefact's traditional designation, such as e-pub and e-journal.

The first digital picturebooks were born in the late 1980's. The publisher Brøderbund released a remarkable collection of picturebooks on CD-ROM to which belongs for example "Arthur's Teacher Trouble" (Brøderbund,1992). These digital narrative interactive books had no significant expansion, for over a decade. Nowadays, because of the format's obsolescence and the software and hardware's evolution, almost no CD-ROMs of this period can be read properly.

The digital picturebooks of this time period, whose diffusion is noteworthy, were the informative ones. The CD-ROMs from Dorling Kindersley, such as The way things work and I love Maths, had numerous translations worldwide, serving as a reference to many other CDROMs.

In the first half of 21st Century the CD-ROM ceased gradually to be used. The Internet has changed and its new features, along with best computer processors and more disk storage, allowed users to access a greater volume of information and receive animations, video and sound more effi- ciently. The contents available only on CD-ROMs, were now provided on the www, which allowed the development of portals dedicated to children, such as The Penguin Club from Disney and Cidade da Malta, with entertaining and informative features. During this time, it became common the digital implementation of printed books, to which were added 
$2^{\text {nd }}$ International Conference

Art, Illustration and Visual Culture

in Infant and Primary Education
Arte, Ilustración y Cultura)

Cultura Visual en Educación Infantil y Primaria
Congresso Internacional

de Arte, llustracão e Cultura Visual

na Educação Infantil e Primária narration and simple linear inter- actions. This practice is still carried out and the catalivros.org site is a recent Portuguese example.

The creation of children's picturebooks specifically for the digital medium had no expression throughout most of this century's first decade.

At the end of the decade began the sale of tablets and smartphones, with access to audio, video, internet and new interaction abilities (multi-touch screens), enabling rich browsing experiences. The compact size, portability and good usability, introduced these devices in several informal children's spaces. In a very short period of time have been released, in many languages, hundreds of digital children's picturebooks. In Bologna, the Children's Book fair (since 1963), one of the leading world events to promote children's picturebooks, also known because of the Bologna Ragazzi Award, was marked in 2012 by the launch, for the first time, of the Digital Bologna Ragazzi Award.

The new picturebooks uses images, sounds and interactions; the whole text results from a combination of various media; the interaction with the screen allows progression on book's narratives and/or information; uses characteristic features of other media, such as cinema plans, camera movements-and videogames-the books can have spaces/games related with the picturebook's theme.

At this expansion time we must find a new terminology to synthesize a name for these new interactive digital picturebooks for children. We propose, therefore, the designation of e-picturebook for these artefacts, establishing links with the original artefact, from which it inherits its main characteristics, whilst highlighting the digital medium through the use of prefix "e". This approach considers a similar process used to naming other mediums, whose terminology, as we already noticed, was made in the same way.

We selected to examine the rationale of a new terminology, four titles from the iPad library, which represent four different approaches, identified in many other e-picturebooks (Table 1).

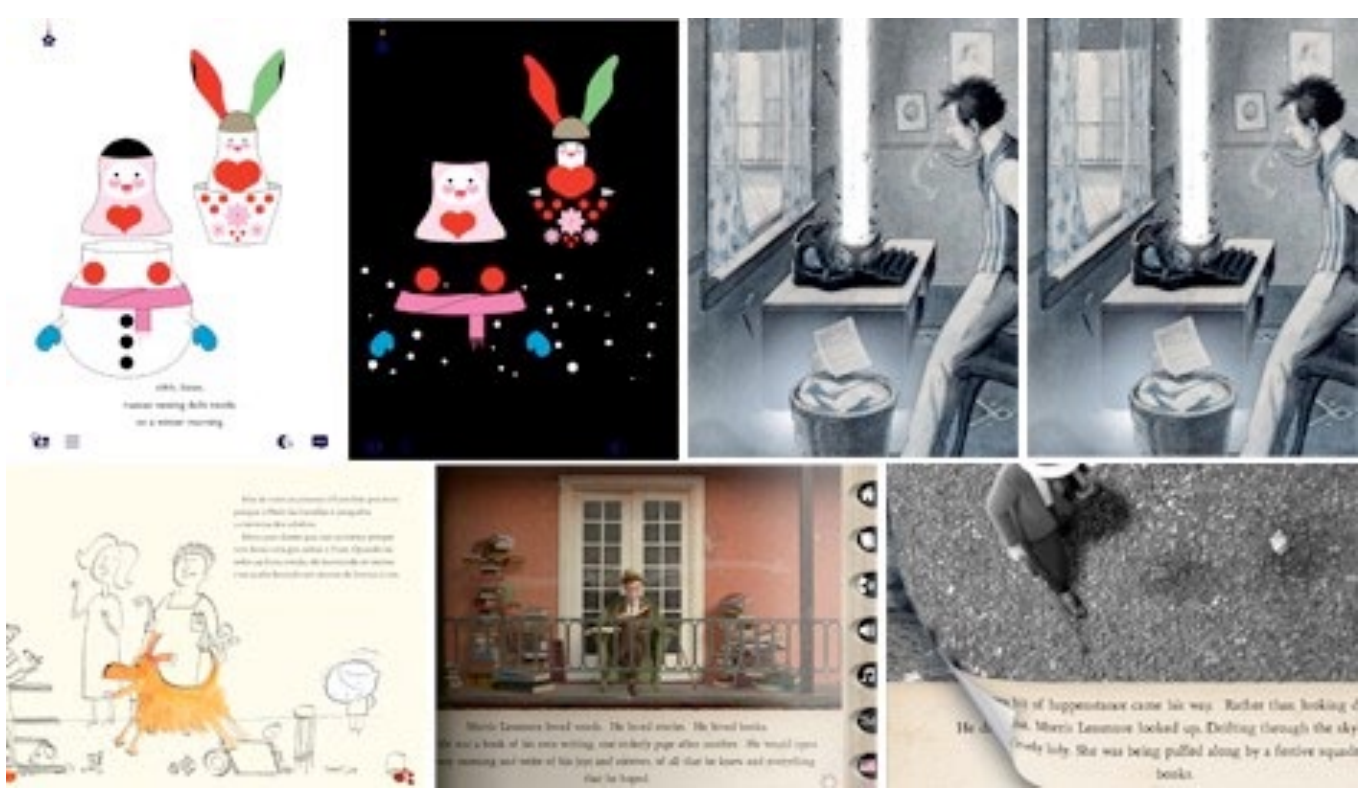

1. Adaptation of a printed book to a digital book (see figures 3 and 4 )

Rocket Book (2011) by Peter Newell is an adaptation of a printed book (published in 1912) with the same name. A boy throws a rocket from the building basement, which crosses twenty floors. The rocket's impact interferes with activities, that neighbour's are developing, causing multiple reac- tions. The illustration, with realistic character and scenery, invokes the time of the original edition, through particular elements, such as clothing, hairstyles and furniture. The illustrations contain an- imated details and a lively track that amplify the effect of rocket on each floor. 
2nd International Conference Art, Illustration and Visual Culture in Infant and Primary Education
Table 1. Analysis of four books with different design approaches

\begin{tabular}{|c|c|c|c|c|c|}
\hline & $\begin{array}{l}\text { Criteria for } \\
\text { selection / } \\
\text { e-picturebook }\end{array}$ & $\begin{array}{l}\text { Device ori- } \\
\text { entation / } \\
\text { Interaction }\end{array}$ & $\begin{array}{l}\text { Metaphors } \\
\text { of a printed } \\
\text { book }\end{array}$ & $\begin{array}{l}\text { Illustration and Text / } \\
\text { Interaction with illustration and text }\end{array}$ & Sound / Music \\
\hline 1 & $\begin{array}{l}\text { Adaptation of } \\
\text { a printed } \\
\text { book } \\
\text { Rocket Book } \\
(2011) \\
\text { Peter Newell }\end{array}$ & $\begin{array}{l}\text { iPad- } \\
\text { Horizontal } \\
\text { (HO) and } \\
\text { Vertical } \\
\text { orientation } \\
\text { (VO) } \\
\text { Touch and } \\
\text { swipe }\end{array}$ & $\begin{array}{l}\text { Book cover } \\
\text { and double } \\
\text { page repre- } \\
\text { sentation: } \\
\text { text on left } \\
\text { and illustra- } \\
\text { tion on right. }\end{array}$ & $\begin{array}{l}\text { HO - double page, similar to the original; text } \\
\text { on left and illustration on right. } \\
\text { Swipe from top to bottom and vice-versa: } \\
\text { changes the double page } \\
\text { VO - the illustration occupies the full screen. } \\
\text { Swipe from left to right - appears the text in } \\
\text { the top of a translucent rectangle; } \\
\text { Swipe from right to left - appears a set of lift } \\
\text { buttons; Swipe from top to bottom and vice- } \\
\text { versa - changes the illustration } \\
\text { Animated with technology of 3-D that gives } \\
\text { depth to original illustrations. }\end{array}$ & $\begin{array}{l}\text { Oral narration; } \\
\text { musical back- } \\
\text { ground typical of } \\
\text { the time featured } \\
\text { in the book; rocket } \\
\text { sounds. }\end{array}$ \\
\hline 2 & $\begin{array}{l}\text { Adaptation of } \\
\text { an animated } \\
\text { movie } \\
\text { The fantastic } \\
\text { flying books } \\
\text { of Mr. Morris } \\
\text { Lessmore } \\
(2011) \\
\text { William Joyce }\end{array}$ & $\begin{array}{l}\text { iPad - } \\
\text { Horizontal } \\
\text { orientation } \\
\text { Touch and } \\
\text { swipe }\end{array}$ & $\begin{array}{l}\text { Representa- } \\
\text { tion of flip- } \\
\text { ping through } \\
\text { a book } \\
\text { (Swipe from } \\
\text { left to right } \\
\text { and vice- } \\
\text { versa) }\end{array}$ & $\begin{array}{l}\text { The book begins with a screen that contains the } \\
\text { book cover with the title and which corre- } \\
\text { sponds to the forefront of the short film. The } \\
\text { narrative consists of a sequence of illustrations, } \\
\text { corresponding to the most important plans from } \\
\text { the short film. } \\
\text { In each plane there are animated details that } \\
\text { emphasize the narrative; some details are } \\
\text { animated and are triggered by interactions. } \\
\text { The illustrations vary between black and white } \\
\text { and colours, on a symbolic way. } \\
\text { At the bottom of the screen is an icon that acti- } \\
\text { vates the navigation, placed on the right verti- } \\
\text { cal, with icons that allow us to configure the } \\
\text { display options of the following elements: text, } \\
\text { narration, language, screen, home. }\end{array}$ & $\begin{array}{l}\text { Oral narration and } \\
\text { musical back- } \\
\text { ground, from orig- } \\
\text { inal short film. }\end{array}$ \\
\hline 3 & $\begin{array}{l}\text { Simple inter- } \\
\text { actions and } \\
\text { linear se- } \\
\text { quences } \\
\text { Quem soltou o } \\
\text { Pum? } \\
\text { Blandina } \\
\text { (2011) } \\
\text { Franco c José } \\
\text { Carlos Lollo }\end{array}$ & $\begin{array}{l}\text { iPad- } \\
\text { Horizontal } \\
\text { orientation } \\
\text { Touch and } \\
\text { swipe }\end{array}$ & $\begin{array}{l}\text { Representa- } \\
\text { tion of flip- } \\
\text { ping through } \\
\text { a book } \\
\text { (Swipe from } \\
\text { left to right } \\
\text { and vice- } \\
\text { versa) }\end{array}$ & $\begin{array}{l}\text { The book screens are fully illustrated, show the } \\
\text { spaces in which the action takes place and con- } \\
\text { tain small animations with Pum. } \\
\text { The sequence of plans is done through } \\
\text { interaction with the buttons located at the } \\
\text { bottom corners and allows go forward or } \\
\text { backward, triggering an animated } \\
\text { representation of flipping through a book. }\end{array}$ & $\begin{array}{l}\text { Beginning of the } \\
\text { book: background } \\
\text { music, with cheer- } \\
\text { ful characteristics, } \\
\text { which disappears } \\
\text { as soon as the } \\
\text { books starts; the } \\
\text { music returns in } \\
\text { the last screen of } \\
\text { the book; several } \\
\text { contextual sounds, } \\
\text { related mainly to } \\
\text { dog's actions. } \\
\text { Oral narration (op- } \\
\text { tional). }\end{array}$ \\
\hline 4 & $\begin{array}{l}\text { Non-linear } \\
\text { interactio } \\
\text { and } \\
\text { narrative } \\
\text { Dans mon } \\
\text { rêve } \\
(2011) \\
\text { Stephane } \\
\text { Kiehl } \\
\text { iPad }\end{array}$ & $\begin{array}{l}\text { iPad } \\
\text { Vertical } \\
\text { orientation } \\
\text { (VO) } \\
\text { Touch and } \\
\text { swipe } \\
\text { Horizontal } \\
\text { orientation } \\
\text { (HO) } \\
\text { Without in- } \\
\text { teraction }\end{array}$ & & $\begin{array}{l}\text { The book title and references to the book's } \\
\text { publisher appeared in the initial screen. } \\
\text { Opening a color rectangle, as a venetian blind, } \\
\text { shows an area of illustration and text, with } \\
\text { three phrases in different rows, on bottom. } \\
\text { The illustration space is divided into three } \\
\text { horizontal bands, which can move in two } \\
\text { directions: left to right and vice-versa. Each } \\
\text { band has } 20 \text { positions, which corresponds to a } \\
\text { distinct sentence. The positions of bands } \\
\text { combined construct a single illustration. The } \\
\text { movement of each band allows hundreds of } \\
\text { image-text combinations. Four icons at the bot- } \\
\text { tom of the application triggers the following } \\
\text { actions: oral narration; change to black the } \\
\text { background colour of the screen; musical } \\
\text { background activation; appearance and disap- } \\
\text { pearance of the text; screens "photographs"; } \\
\text { gallery with photographed images. Screen rota- } \\
\text { tion from VO to HO: star-shaped mask and a } \\
\text { pink star, in motion, showing the illustration's } \\
\text { behind. }\end{array}$ & $\begin{array}{l}\text { The movement of } \\
\text { each band } \\
\text { corresponds to a } \\
\text { different sound. } \\
\text { Oral narration. }\end{array}$ \\
\hline
\end{tabular}


and International Conference Art, Illustration and Visual Culture in Infant and Primary Education de Arte, llustração e Cultura Visual

na Educação Infantil e Primária

2. Adaptation of an animated movie to an e-picturebook (see figures 6 and 7)

The fantastic flying books of Mr. Morris Lessmore by William Joyce, (2011) is an adaptation, with the same name, from a short film.

The narrative is a metaphor that emphasizes the power of books, in the readers' lives, even in adversity, through a librarian's life. The characters representation, their costumes and sceneries, transport us to America, in the 40 s.

\section{E-Picturebook with simple interactions and linear sequences (see figure 5) Quem soltou o Pum? Blandina Franco e José Carlos Lollo (2011)}

A child has a dog-named Pum, to who removes the leash so they can play; this action triggers many problems at home. The text may have two distinct readings due to dog's name and to the double meaning from the expression "soltar o Pum".

\section{Non-linear interaction and narrative (see figures 1 and 2) Dans mon rêve | Stephane Kiehl (2011)}

Dreamlike narratives that transport us to an unreal space, inhabited by strange creatures, with details from impossible scenarios and poetic texts.

\section{Conclusions}

Through the observations it was confirmed that e-picturebooks are anchored in picturebooks, in how they use the image and verbal text and in the way both establish, between the used mediums, semantic relationships. We also observed that the image - static and animated assumes in communication prevalence over other mediums used in e-picturebooks. However, the use of other medium in the e-picturebooks - sound, animation and video - potentiates new semantics relationships that shall be studied in future and justifies the new terminology of e-picturebook. In general, we ob- serve that background music emphasizes the story's feelings; the context's sound highlights the in- teractions or the narrative's actions; the oral narration provides a second access to the verbal text; the interaction is presented as a narrative tool to unravel particular communication's aspects and al- lows modifying the narrative, spatially and temporally; the computing device's characteristics as- sume an important role in elements choices' to interfaces and narratives.

The diversity and quantity of e-picturebooks observed allowed us to confirm that this type of book holds a significant place that justifies the development of studies around them; a research comparing the children's reading of printed books and e-picturebooks, must be carried out; exploring the educational potential of this type of books, will be other research to consider.

\section{Bibliographical references}

Anstey, M. (2008). Postmodern picturebook as artefact: developing tools for an archaeological dig. Postmodern Picturebooks: play, parody and self-referentiality. L. R. Sipe and S. Pantaleo. New York, Rouledge. 16.

Brøderbund (1992). Arthur's Teacher Trouble, Broderbund Software Inc

Chrystal, R. (2009) "The Evolution of e-Books: Technology and Related Issues." Digital Libraries INFO 653

Professor Xia Lin. Escarpit, D. (1996). La ilustración en libros infantiles y juveniles. Peonza. Santander. Franco, B. and J. C. Lollo (2011). Quem soltou o Pum? E. S. Ltda.

Hillesund, T. (2010). "Digital reading spaces: how expert readers handle books, the web and electronic paper." First Monday 15.

Joyce, W. (2011). The fantastic flying books of Mr. Morris Lessmore, Moonbot studios.

Kiefer, B. (2008). What is a picturebook anyway? The evolution of form and substance through the postmodern era and beyond. Postmodern Picturebooks: play, parody and self-referentiality. L. R. Sipe and S. Pantaleo. New York, Rouledge. 16.

Kiehl, S. (2011). In my dream. 
2nd International Conference Art, lllustration and Visual Culture in Infant and Primary Education $2^{\circ}$ Congreso Internacional Arte, Ilustración y Cultura Visual en Educación Infantil y Primaria
${ }^{\circ}$ Congresso Internacional

de Arte, llustração e Cultura Visual na Educação Infantil e Primária

Kress, G. (2000). Multimodality. Multiliteracies: Literacy learning and the design of social futures. B. Cope and M. Kalantzis, Routledge.

Mangen, A. (2008). "Hypertext fiction reading: haptics and immersion." Journal of Research in Reading 31(4): 404-19.

Newell, P. (2011). The rocket book, Third Bird Party!

Nikolajeva, M. (2002). The verbal and the visual: the picturebook as a medium. Children's Literature as Communication: The ChiLPA project. R. D. Sell. Amsterdamll/IPhiladelphia, John Benjamins Publishing Company.

Nikolajeva, M. (2010). Interpretative codes and implied readers of children picturebooks. New directions in picturebook research. T. Colomer, B. Kümmerling-Meibauer and C. Silva-Díaz. New York, Routledge: 261.

Sipe, L. R. (2012). "Revisiting the relationships between text and pictures." Children's Literature in Education 43(1): 4-21.

Wolfenbarger, C. D. and L. R. Sipe (2007). "A unique visual and literary art form: recente research on picturebooks." Language Arts 84(3): 273-80. 